\title{
With Whitman at the Friendship Hotel Anthony Piccione
}

I call out crazed in fever in a room

in Peking where I've come afraid and alone to find, something, the words maybe.

My family looks out from the gulf behind their photographs on the rickety desk.

So I stand. With a bottle of red wine and no talk for days, no talk from my neighbors rushed and far flung, the Chinese frozen in awe untouching, and here, in the chest of all that is lost, I read, out loud, Walt Whitman.

Someone's voice cracks, gathers, grows calm by my feet on the green wash of rug, and waves this meeting aside. Brother, brother, here is our home. Who knows what powers the world! I love the man. 